\title{
Comparative Evaluation of Casting Method over Standing Method of Castration in Bulls: A Clinical Study
}

\author{
G.U. Yadav*, D.U. Lokhande, A.U. Bhikane and A.T. Yamgar
}

Department of Surgery and Radiology, Bombay Veterinary College, Parel, Mumbai -12, India

\author{
*Corresponding author
}

\section{A B S T R A C T}

\begin{tabular}{|l|}
\hline Key w or d s \\
Casting method, \\
Standing method, \\
Castration, Travis \\
\hline Article Info \\
\hline $\begin{array}{l}\text { Accepted: } \\
\text { 07 January } 2019 \\
\text { Available Online: } \\
\text { 10 February } 2019\end{array}$ \\
\hline \hline
\end{tabular}

Keywords

Casting method, Standing method, Castration, Travis

Article Info

07 January 2019

10 February 2019
Twenty four bulls presented for castration to Department of Surgery and Radiology, Bombay Veterinary College Parel, BSDPHA affiliated hospital and Department of TVCC, COVAS, Udgir were studied for comparative evaluation of casting method and sanding method of castration in bulls. All the animals were sedated with Xylazine @ $0.02 \mathrm{mg} / \mathrm{kg}$ BW, IM 30 minutes before castration. In 12 animals traditional casting method was applied for castration and in other 12 animals standing method of castration was used. The standing castration was performed by fixation of animals in Travis. The hind limbs were tied to side rails of Travis separately and the scrotal bag was pulled back. The spermatic cords were located and castration was performed. Standing method of castration is safe, less time consuming with no accidental crushing of penis, and can be performed without complications like radial nerve paralysis, bone and muscle injuries.

\section{Introduction}

Bloodless castration technique by using burdizzo castrator is commonly practiced under field conditions. Another satisfactory method of castration is complete ablation of scrotal sac under tranquilization and local anaesthesia (Tyagi and Singh, 1996). Irrespective of open or close technique, casting of animal on ground is mandatory in both the methods of castration. Present report deals with comparative study of clinical cases of castration performed in standing and casting position in bulls.

\section{Materials and Methods}

Twenty four clinical cases of bulls of various breeds presented for castration to Department of Surgery and Radiology, Bombay Veterinary College Parel, BSDPHA affiliated hospital and Teaching Veterinary Clinical Complex, Udgir formed the clinical material for the present study. The percentage of cases in relation to species, breed, and age were studied. The duration required for regression of hump, changes in skin coat, time required for regression of testicle and changes in length and breadth of testicle were studied. 
All the animals in both groups were given sedation with Xylazine @0.02mg/kg BW, IM half hour before surgical intervention of castration and after development of sedation the castrations were performed.

The routine method of castration by casting the animal on ground was performed in 12 animals. After casting of animal the German made asculep castrator was attempted in 12 animals (Fig. 1).

Other 12 animals were restrained in Travis by tying the hind limbs separately to side rails of travis and the head of animal was restrained front side poll or bar of Travis. After proper restraining in standing position the scrotal bag of animal was pulled backward to the maximum possible extant (Fig. 2) and spermatic cords were located by taking all the aseptic precautions and asculep was applied on spermatic cord to crush spermatic cord for 2 minutes (Fig. 3), similar procedure was applied for crushing of spermatic cord to the other side. The animals in this group were castrated by application of German made asculep in the standing position. The castration sites were dressed with Tincture Iodine for three days. Streptopenicillin@10 $\mathrm{mg} / \mathrm{kg}$ body weight was given for 3 days and Meloxicam was given @0.3mg/kg body weight for 3days. Clinical parameters of all the animals were recorded in terms of heart rate, respiration rate and rectal temperature before and after castration. Healing of surgical wounds, post operative libido, sex behaviour etc were recorded post operatively. Comparative aspects and effectiveness of the above methods was also studied.

\section{Results and Discussion}

Castration in bovines is performed to render the male animals docile and also to improve the quality of flesh (Amresh Kumar, 1996). In the present study all the 24 animals presented for castration were bovines. Out of total 24 animals presented $50 \%$ (12) animals were nondescript, $33 \%$ (8) animals were Red Khandari and $16.66 \%$ (4) animals were Deoni. All the animals presented for castration were of 2 to 5 years age group and no animals above 5 year age were presented for castration. However O'Conner (1980) suggested that castration in cattle can be performed at the age of 6 weeks to 6 months.

Xylazine sedation was found useful for castration in both methods. Oehme (1998) advised standing method of castration in horses under chloral hydrate sedation and local anaesthesia. Routine casting method was used in 12 cases and standing castration method was applied in other 12 animals. O'Connor (1980) reported the standing method of castration by holding the animal against the wall or partition and applying nose ring. He also suggested that the horns of animals should be tied and kicking trap must be applied over the hocks to control the animals by complete fixation. Whereas, Tyagi and Singh (1996) suggested that casting method is most suitable for castration in bovines.

The physiological parameters like heart rate $(49.45 \pm 1.32 / \mathrm{min}$ in group I and $49.09 \pm 1.31$ min in group II), respiration rate $(23.45 \pm 0.62$ in group I and $24.72 \pm 0.73 \mathrm{~min}$ in group II) and rectal temperature $(101.09 \pm 0.21 \mathrm{f}$ in group I and $100.91 \pm 0.15^{0} \mathrm{f}$ in group II) were normal in both the methods before and after castration during 50 days of monitoring period.

Strepto-penicilln given post operatively had provided antibiotic coverage and meloxicam provided antinflammatory effect to reduce the swelling at the site. Daily dressing with Tincture Iodine helped to prevent the bacterial contamination at the site. Post operative healing of scrotal wounds was normal in all 
the cases in 8-10 days and no any complication was observed in both the groups.

The development of hump presented for castration was more in $41.66 \%$ (10) animals and moderate in $58.33 \%$ (14) animals, but hump development was observed in all the animals before castration. The moderate hump regression was observed in $59.72 \pm 1.80$ days of castration in group I and $61.81 \pm 1.31$ in group II but complete regression was not observed in any of the case after castration. Rough skin coat was observed in all the animals presented for castration and the changes in skin coat i.e. moderate smoothness of skin coat was observed in the animals upto
$52.27 \pm 1.06$ in group I and $53.27 \pm 1.00$ days in group II after castration. The average length of testicles was 5 inches and breadth was 4.37 inches before castration operation. The testicles were regressed normally within $46.09 \pm 0.86$ days after castration in group I

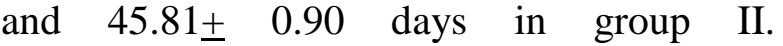
Venugopalan (1994) reported that 30 days are required for complete regression of testicles after close method of castration. The libido and sex behaviour were found to be reduced within $90.54 \pm 1.30$ days in group I and in $90.00 \pm 1.07$ days in group II animals. The comparative aspects of standing castration method versus casting method were as follows.

Table.1

\begin{tabular}{|c|c|c|}
\hline Sr. No. & Standing castration Method & Casting castration method \\
\hline 1 & Easy to operate and easy to perform. & Casting procedure is risky and difficult to perform. \\
\hline 2 & Requires less time and labours. & Requires more time and labours. \\
\hline 3 & $\begin{array}{l}\text { Can be performed in any season and } \\
\text { weather. }\end{array}$ & Only recommended in winter or cooler and dry season. \\
\hline 4 & $\begin{array}{l}\text { Chances of contamination at site of } \\
\text { castration i.e. castrator bite marks at the } \\
\text { base of testicle are less during surgery. }\end{array}$ & $\begin{array}{l}\text { Due to casting the area where castrator bite marks are } \\
\text { present may come in contact with soil and more chances } \\
\text { of contamination during castration. }\end{array}$ \\
\hline 5 & $\begin{array}{l}\text { No need of casting only restraining in } \\
\text { standing position is required. }\end{array}$ & Needs casting. \\
\hline 6 & $\begin{array}{l}\text { Post surgical complications are not } \\
\text { observed. }\end{array}$ & $\begin{array}{l}\text { Chances of soiling of wound and contamination were } \\
\text { present. }\end{array}$ \\
\hline 7 & $\begin{array}{l}\text { Position of spermatic cord is clear, } \\
\text { evident, easily palpable and not were } \\
\text { overlapping to each other. }\end{array}$ & $\begin{array}{l}\text { In casting method the spermatic cord remains horizontal } \\
\text { in position overlapping with each other due to } \\
\text { recumbent position of the animal so difficult. }\end{array}$ \\
\hline 8 & $\begin{array}{l}\text { Spermatic cords are clearly visible and } \\
\text { palpable so castration can be performed } \\
\text { easily. }\end{array}$ & $\begin{array}{l}\text { For crushing of spermatic cord careful location and } \\
\text { palpation is required. }\end{array}$ \\
\hline 9 & $\begin{array}{l}\text { The chances of accidental crushing of } \\
\text { penis is not possible }\end{array}$ & Accident \\
\hline 10 & $\begin{array}{l}\text { No complications like radial nerve } \\
\text { paralysis, muscle injury, injuries to } \\
\text { body parts, injuries to horns, tympany } \\
\text { and fracture. }\end{array}$ & $\begin{array}{l}\text { Complications likely to occur. Casting may lead to } \\
\text { radial nerve paralysis, muscle injury, injuries to body } \\
\text { parts, injuries to horns, tympany and fracture. }\end{array}$ \\
\hline 11 & $\begin{array}{l}\text { Animal is comfortable during castration } \\
\text { in standing method. }\end{array}$ & $\begin{array}{l}\text { Some discomfort to the animal due to casting may } \\
\text { occur. }\end{array}$ \\
\hline
\end{tabular}


Fig.1 Traditional casting method

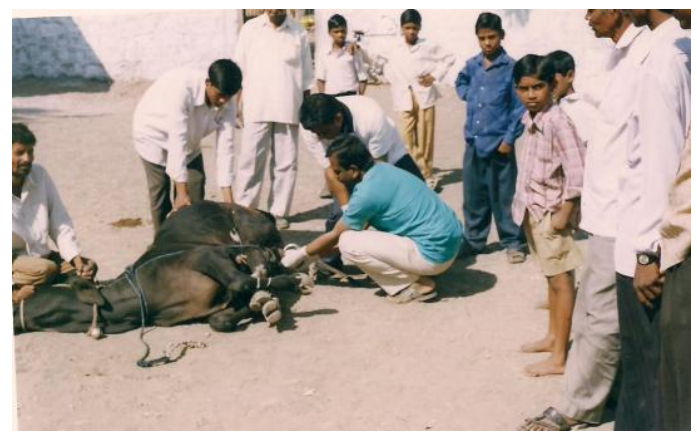

Fig.2 Location of spermatic cords after restraining the animal

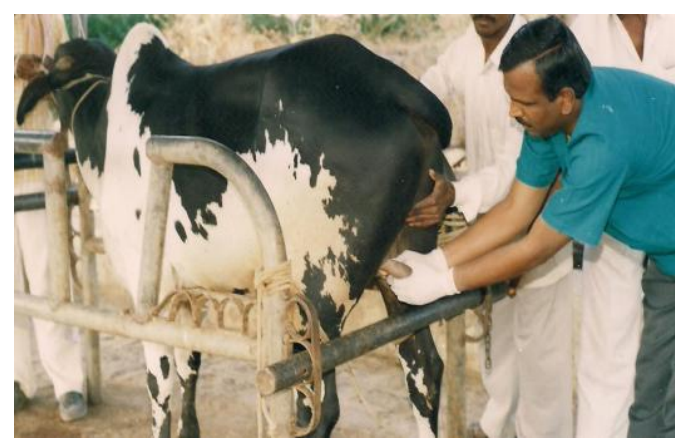

\section{References}

Kumar.A. (1996) Veterinary surgical techniques. Vikas Publishing House. Pvt. Ltd. New Delhi.

O’Conner J.J. (1980) Dollars Veterinary Surgery $4^{\text {th }}$ Edn. CBS, Publishers and Distributers, Delhi.

Oehme, F.W.C. (1988) Textbook of large Animal Surgery $2^{\text {nd }}$ edition. Williams
Fig.3 Castration by standing method of castration

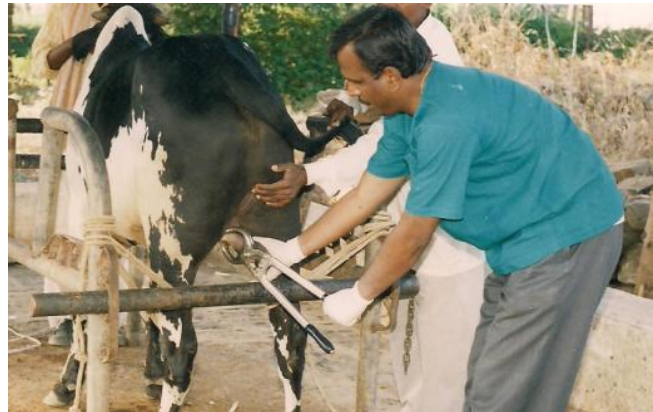

and Wilkins, Sydney.

Tyagi R.P.S. and Singh J.P.(1996) Ruminant Surgery, CBS Publishers and Distributors Delhi

Venugopalan A. (1994) Essentials of Veterinary Surgery, Oxford and IBH Publishers Co. Pvt. Ltd. Bombay.

\section{How to cite this article:}

Yadav, G.U., D.U. Lokhande, A.U. Bhikane and Yamgar, A.T. 2019. Comparative Evaluation of Casting Method over Standing Method of Castration in Bulls: A Clinical Study. Int.J.Curr.Microbiol.App.Sci. 8(02): 693-696. doi: https://doi.org/10.20546/ijcmas.2019.802.079 